\title{
Seasonal Incidence and Influence of Weather Factors on the Population Dynamics of Sugarcane Web Mite, Schizotetranchyus andropogoni Hirst on Sugarcane
}

\author{
K.S. Karthick ${ }^{1}$, C. Chinniah ${ }^{1 *}$, T. Ramasubramanian², M. Kalyanasundram ${ }^{3}$, \\ K. Devrajan ${ }^{4}$ and N.S. Venkataraman ${ }^{5}$ \\ ${ }^{1}$ Department of Agricultural Entomology, AC \& RI, Madurai-625 104, India \\ ${ }^{2}$ Division of Crop Protection, ICAR, Sugarcane Breeding Institute, \\ Coimbatore - 641 007, India \\ 3(Agriculture), TNAU, Coimbatore - 641 003, India \\ ${ }^{4}$ (Nematology), TNAU, Coimbatore - 641 003, India \\ ${ }^{5}$ Department of Agronomy, AC \& RI, Madurai - 625 104, India
}

*Corresponding author

A B S T R A C T

Keywords

Schizotetranchyus andropogoni,

Sugarcane,

Population

dynamics, Weather

factors

Article Info

Accepted:

15 June 2019

Available Online:

10 July 2019
A study was conducted to assess the population dynamics of sugarcane web mite, Schizotetranchyus andropogoni Hirst during June 2017 to May 2018 in field condition at Sugarcane Research Station (SRS), Cuddalore district. The population density of sugarcane web mite, S. andropogoni of mite touched its peak (10.45 mites / $2 \mathrm{~cm}^{2}$ area of leaf) during the first week of May 2018 ( $18^{\text {th }}$ SMW) and the mite population declined during the first week of September 2017 (35 ${ }^{\text {th }}$ SMW) to last week of December 2017 (8.43 to 4.53 mites $/ 2 \mathrm{~cm}^{2}$ area of leaf). The web mite population had a significant positive correlation with maximum temperature $\left(r=0.927^{* *}\right)$, minimum temperature $\left(\mathrm{r}=0.774^{* *}\right)$ and a negative correlation with relative humidity $\left(\mathrm{r}=-0.729^{* *}\right)$ and rainfall $\left(\mathrm{r}=-0.312^{*}\right)$ and non-significant positive correlation with wind velocity $\left(0.107^{\mathrm{NS}}\right)$

\section{Introduction}

Sugarcane, Saccharum officinarum L. is one of the most important sources of cane sugar in the world which is cultivated in India. India is the original land of origin of Saccharum species. The world largest producer of sugarcane is Brazil followed by India.
Sugarcane is cultivated in an area is 26.2 million ha, 1877.10 MT with the production in the world coupled with the productivity of 70.77 tonnes/ha. Whereas Indian scenario in quiet different i.e., sugarcane is cultivated in an area of 5.42 million ha, with a production of 4.11 million tonnes and a productivity of 81.50 tonnes/ha (Anonymous, 2018). The 
important zones for sugarcane cultivation in India are Tropical and Subtropical regions which are grouped into five agro-climatic zones, mainly for varietal development. They are North Western Zone, North Central Zone, North Eastern Zone, Peninsular Zone and Coastal Zone. Plant-inhabiting mites are important components of agro ecosystems, and they exhibit diverse feeding habits including phytophagous, predatory, mycophagous and saprophytic species (Hoy, 2011). Sugarcane is attacked by a variety of mite species falling under the major phytophagous families viz., Tetranychidae, Tarsonemidae, and Eriophyoidea. In general the mites are considered as minor pests. Among these nine species of superfamily Eriophyoidea have been reported on sugarcane, they are Abacarus delhiensis, A. queenslandienis, A. doctus, A. sacchari, Aceria sacchari, A. merwei, Cathetacarus spontaneae, Catarhinus sacchari and Diptacus sacchari (Ozman - Sullivan et al., 2006). The incidence of these mite species as pest was first recorded by Hirst (1926). Banerjee (1988) recorded $S$. andropogoni (Hirst) as a serious pest of sugarcane in India, besides several insect pests. Apart from insect pests, mites cause considerable yield loss (up to 20-30 \%) on sugarcane (Ghoshal and Barman, 2012). In present investigation the population dynamics of web mite, $S$. andropogoni Hirst and influence of weather factors on mite population dynamics of sugarcane has been investigated in this study.

\section{Materials and Methods}

The influence of weather parameters on the population dynamics of $S$. andropogoni on sugarcane variety (Co 86032) was studied at Sugarcane Research Station (SRS), Cuddalore, TNAU during June 2017 to May 2018. To monitor the population fluctuation of $S$. andropogoni ten plants were tagged at random in the field and the observations of mite population was recorded three leaves. On the population was recorded at weekly interval. These were labelled and brought to the laboratory for observation and counting of mite. After that ten leaf bits were cut each measuring approximately $2 \mathrm{~cm}^{2}$ area which were utilized for counting under a stereo zoom microscope. The weather parameters viz., maximum temperature $\left({ }^{0} \mathrm{C}\right)$, minimum temperature $\left({ }^{0} \mathrm{C}\right)$, relative humidity $(\%)$, rainfall $(\mathrm{mm})$, wind velocity $(\mathrm{km} / \mathrm{hr})$ were gathered from the automatic weather station maintained at Sugarcane Research Station, Cuddalore. The correlation and regression was worked out based on the influence of weather factors on population density of sugarcane leaf mite adopting the method as suggested by Goulden (1972).

\section{Results and Discussion}

The field investigation revealed (Table 1) that the occurrence of sugarcane web mite, $S$. andropogoni throughout the season. However the population density ranged from 4.53 to $10.45 / 2 \mathrm{~cm}^{2}$ area of leaf, during June 2017 to May 2018. The density of mite reached its peak (10.45 mites / $2 \mathrm{~cm}^{2}$ area of leaf) during first week of May 2018 ( $18^{\text {th }}$ SMW) which declined during first week of September 2017 $\left(35^{\text {th }}\right.$ SMW) to last week of December 2017 ( 8.43 to 4.53 mites $/ 2 \mathrm{~cm}^{2}$ area of leaf) and this low population of mite can be attributed to the prevalence of moderate temperature (maximum and minimum) and high relative humidity coupled with high rainfall (Fig. 1).

From the present investigation, it is evident that the web mite, $S$. andropogoni population on sugarcane had a significant positive correlation with maximum temperature $(\mathrm{r}=$ $\left.0.927^{* *}\right)$, minimum temperature $\left(r=0.774^{* * *}\right)$ and a negative correlation with relative humidity $\left(r=-0.729^{* *}\right)$ and rainfall $(r=-0$. $\left.312^{*}\right)$ and non-significant positive correlation with wind velocity $\left(0.107^{\mathrm{NS}}\right)$ (Table 2). 
Fig.1 Population dynamics of sugarcane web mite, S. andropogoni on sugarcance relation with weather paramaters (During June 2017 - May 2018)

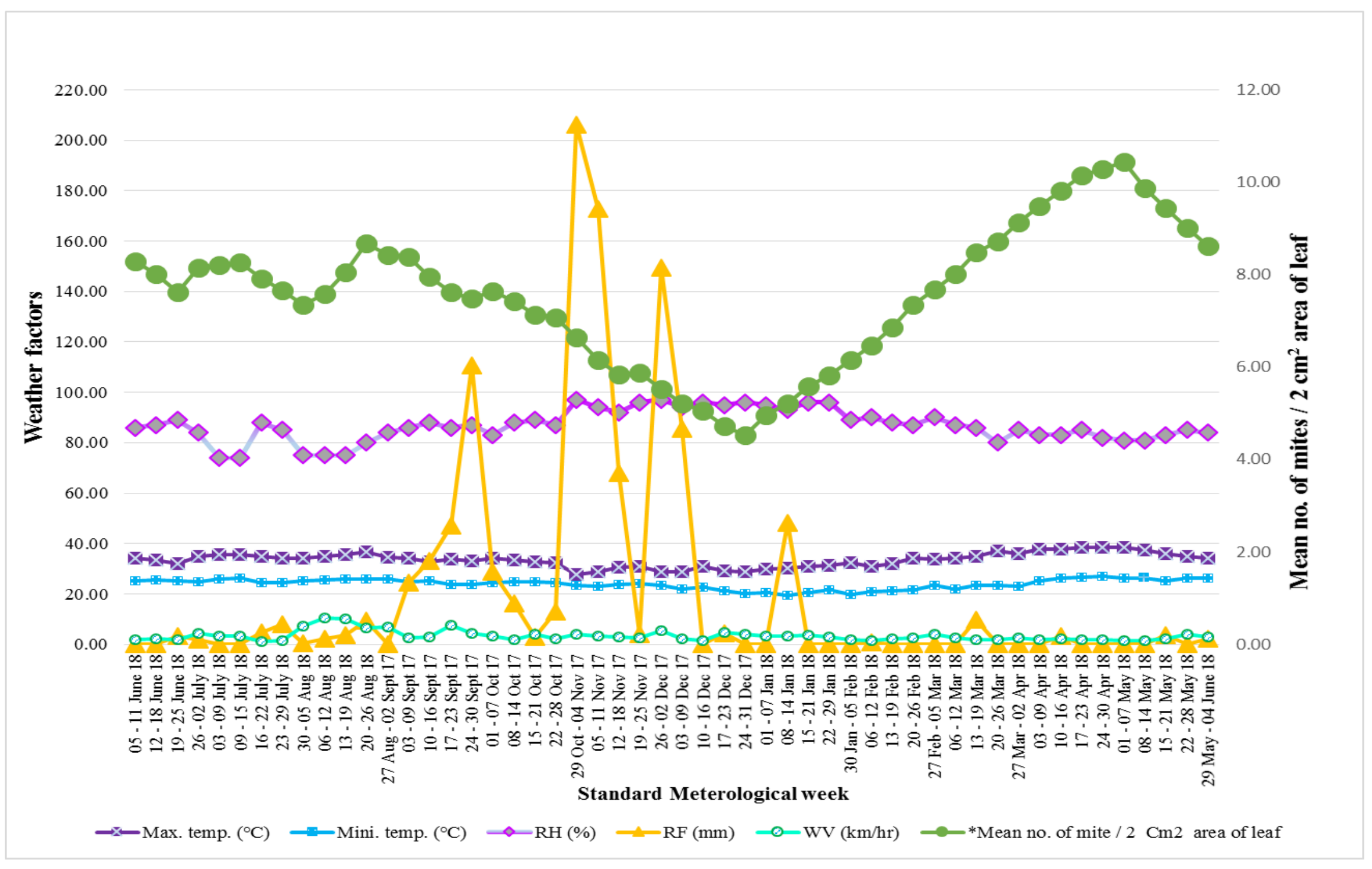


Table.1 Influence of weather parameters on sugarcane web mite, S. andropogoni on sugarcance (Location: Sugarcane Research Station, Cuddalore (TNAU) during June 2017 - May 2018)

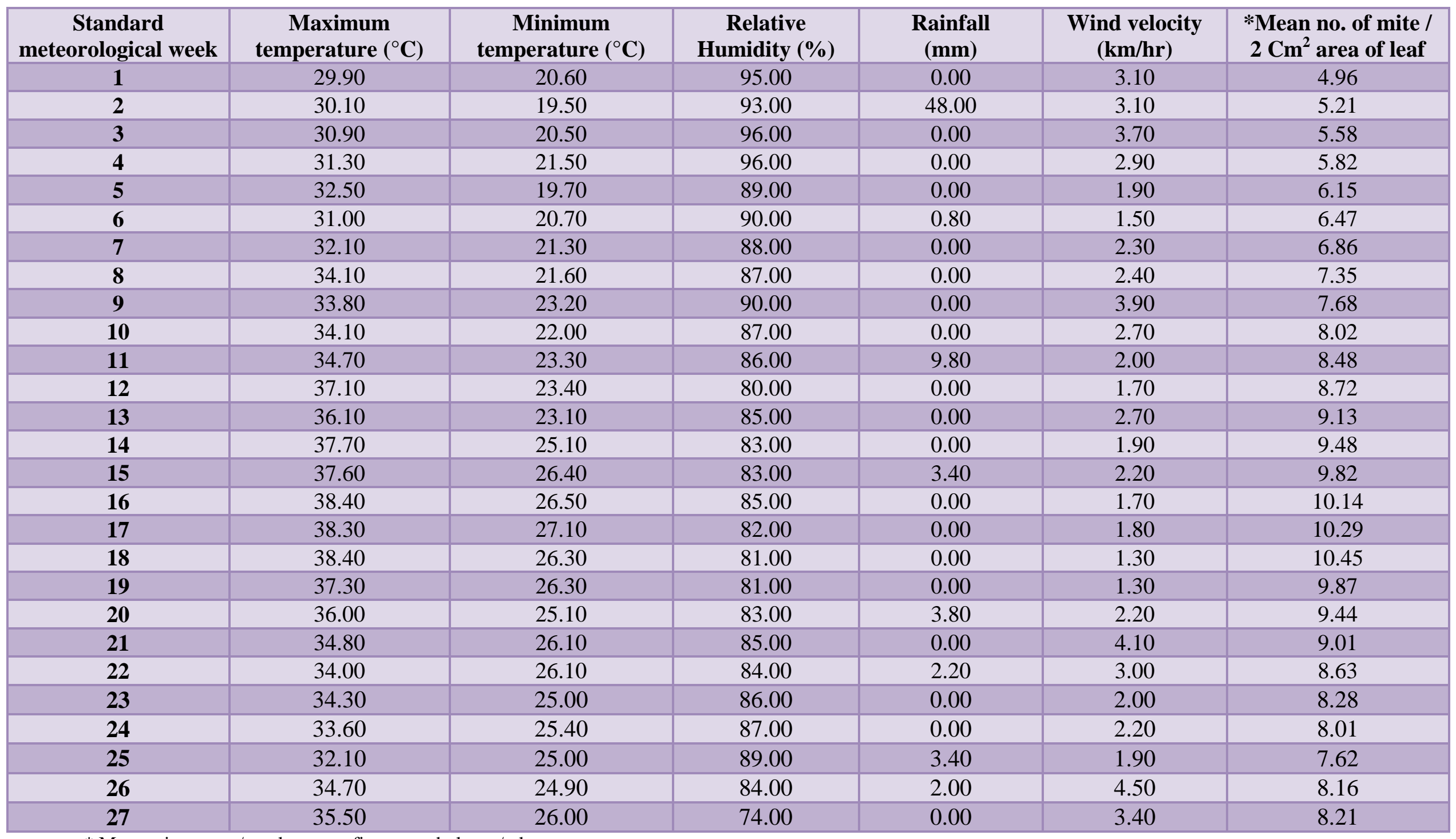

* Mean mite count / ten leaves at five tagged plants / plot 
Table.1 Influence of weather parameters on sugarcane web mite, S. andropogoni on sugarcance (Location: Sugarcane Research Station, Cuddalore (TNAU) during June 2017 - May 2018) (Contd..)

\begin{tabular}{|c|c|c|c|c|c|c|}
\hline $\begin{array}{c}\text { Standard } \\
\text { meteorological } \\
\text { week }\end{array}$ & $\begin{array}{c}\text { Maximum } \\
\text { temperature }\left({ }^{\circ} \mathrm{C}\right)\end{array}$ & $\begin{array}{c}\text { Minimum } \\
\text { temperature }\left({ }^{\circ} \mathbf{C}\right)\end{array}$ & $\begin{array}{c}\text { Relative } \\
\text { Humidity }(\%)\end{array}$ & $\begin{array}{l}\text { Rainfall } \\
\text { (mm) }\end{array}$ & $\begin{array}{l}\text { Wind velocity } \\
(\mathrm{km} / \mathrm{hr})\end{array}$ & $\begin{array}{c}\text { *Mean no. of mite } \\
\text { / } 2 \mathrm{Cm}^{2} \text { area of } \\
\text { leaf }\end{array}$ \\
\hline 28 & 35.50 & 26.30 & 74.00 & 0.00 & 3.30 & 8.27 \\
\hline 29 & 34.90 & 24.30 & 88.00 & 4.60 & 1.00 & 7.92 \\
\hline 30 & 34.20 & 24.50 & 85.00 & 8.00 & 1.40 & 7.66 \\
\hline 31 & 34.00 & 25.20 & 75.00 & 0.30 & 7.30 & 7.35 \\
\hline 32 & 34.80 & 25.70 & 75.00 & 2.20 & 10.60 & 7.58 \\
\hline 33 & 35.60 & 25.90 & 75.00 & 3.80 & 10.10 & 8.05 \\
\hline 34 & 36.70 & 25.90 & 80.00 & 9.20 & 6.60 & 8.68 \\
\hline 35 & 34.57 & 25.91 & 84.00 & 0.00 & 6.80 & 8.43 \\
\hline 36 & 34.23 & 24.71 & 86.00 & 24.60 & 2.70 & 8.38 \\
\hline 37 & 32.64 & 25.17 & 88.00 & 33.20 & 2.80 & 7.96 \\
\hline 38 & 33.77 & 23.83 & 86.00 & 47.20 & 7.70 & 7.63 \\
\hline 39 & 33.22 & 23.83 & 87.00 & 110.60 & 4.20 & 7.48 \\
\hline 40 & 34.26 & 24.54 & 83.00 & 28.60 & 3.10 & 7.65 \\
\hline 41 & 33.47 & 24.86 & 88.00 & 16.20 & 1.90 & 7.42 \\
\hline 42 & 32.84 & 24.91 & 89.00 & 2.80 & 4.00 & 7.13 \\
\hline 43 & 32.20 & 24.51 & 87.00 & 13.00 & 2.30 & 7.07 \\
\hline 44 & 27.74 & 23.23 & 97.00 & 206.00 & 4.10 & 6.65 \\
\hline 45 & 28.65 & 22.90 & 94.00 & 172.60 & 3.30 & 6.16 \\
\hline 46 & 30.65 & 23.90 & 92.00 & 68.00 & 2.80 & 5.83 \\
\hline 47 & 30.80 & 24.20 & 96.00 & 4.00 & 2.50 & 5.88 \\
\hline 48 & 28.75 & 23.50 & 97.00 & 149.40 & 5.40 & 5.52 \\
\hline 49 & 28.85 & 22.00 & 94.00 & 85.60 & 2.20 & 5.21 \\
\hline 50 & 30.80 & 22.70 & 96.00 & 0.00 & 1.60 & 5.05 \\
\hline 51 & 29.00 & 21.30 & 95.00 & 4.40 & 4.60 & 4.72 \\
\hline 52 & 28.65 & 20.10 & 96.00 & 0.00 & 3.90 & 4.53 \\
\hline
\end{tabular}


Table.2 Correlation co-efficient (r), regression between weather parameters and mean number of S. andropogoni population (Location: Sugarcane Research Station, Cuddalore (TNAU) during June 2017 - May 2018)

\begin{tabular}{|l|c|c|c|}
\hline \multicolumn{1}{|c|}{ Weather factors } & $\begin{array}{c}\text { Correlation co- } \\
\text { efficient (r) }\end{array}$ & $\begin{array}{c}\text { Regression equation } \\
\text { value }\end{array}$ & $\mathbf{R}^{\mathbf{2}}$ \\
\hline Maximum temperature $\left.\mathbf{(}^{\mathbf{0}} \mathbf{C}\right)$ & $0.927 * *$ & $\mathrm{Y}=-9.388+0.506 \mathrm{X}$ & 0.859 \\
\hline Minimum temperature $\left.\mathbf{(}^{\mathbf{0}} \mathbf{C}\right)$ & $0.774 * *$ & $\mathrm{Y}=-6.524+0.587 \mathrm{X}$ & 0.599 \\
\hline Relative humidity $(\mathbf{\%})$ & $-0.729 * *$ & $\mathrm{Y}=22.968-0.178 \mathrm{X}$ & 0.532 \\
\hline Rainfall (mm) & $-0.312 *$ & $\mathrm{Y}=7.755-0.011 \mathrm{X}$ & 0.097 \\
\hline Wind velocity (km/hr) & $0.107 \mathrm{NS}$ & $\mathrm{Y}=7.802-0.079 \mathrm{X}$ & 0.012 \\
\hline
\end{tabular}
*Correlation is significant at 0.05\% level (2 tailed)
**Correlation is significant at $0.01 \%$ level (2 tailed)
NS - Non significant

From the linear regression equation fit, it is evident that an increase in maximum temperature by $1{ }^{0} \mathrm{C}$ there was an increase of $S$. andropogoni population by 0.506 per cent. However an increase in relative humidity by one percent there was a decrease in $S$. andropogoni population by 0.178 per cent, however for every $1 \mathrm{~mm}$ increase in rainfall, the mite population declined by 0.011 per cent. The Simple correlation worked out for wind velocity for web mite, S. andropogoni population revealed no significant impact on the population dynamics on sugarcane (Table 2).

The present findings are in conformity with the publications of Bairwa and Singh (2013) who studied the impact of weather parameters on sugarcane leaf mite, $S$. andropogoni (Hirst) and the maximum mean population of egg, nymph and adult mite was recorded (7.59, 3.36 and 5.22 / colony/ leaves) during June 2011 and July 2011 respectively. The temperature (-2.51) and rainfall (0.44) was non-significant co-relation were observed on mite influence and significant relation was recorded by relative humidity (4.80). The influence of temperature and relative humidity build up the population mite was recorded. Gupta (1975) reported that severe infestation of $S$. andropogoni (Hirst) on paddy, West Bengal during August September 1972 which gradually declined during October and disappeared at the end of November. Verma (1976) conveyed that $S$. andropogoni (Hirst) was sporadic pest of sugarcane and in severe infestation 2500 3000 webs/leaf were observed in Lucknow, India. In autumn planted crop the live mite webs were maximum whereas minimum in crop planted during spring in Uttar Pradesh, during 1977 (Tewari et al., 1982). In young and ratoon cane plants has moderate occurrence of spider mite, Oligonychus sp population in dry weather during September 2002 and also mite occurs in sugarcane varieties viz., Co-419, Co-62175 and Co-8371 was recorded during March 2002 and reached peak in May 2002 in Mandya, Karnataka (Gubbaiah and Chakravarthy, 2002). In sorghum variety (Co 26) mite the population ranged from 12 to $55 / \mathrm{Cm}^{2}$ area of leaf during Kharif season at Coimbatore (Mohan and Karuppuchamy, 1987). Dubey et al., (1988) reported that incidence of Oligonychus indicus population was high during hot weather condition $\left(30^{\circ} \mathrm{C}\right)$, which prevailed during July. Sugarcane mite, O. indicus was active beginning from January and the maximum activity was recorded in May (Anonymous, 2002-2007). Deshmukh (2000) stated that the mite, $O$. indicus started 
building up from $34^{\text {th }}$ standard week (STW), third week of August $(0.50$ mites $/ 2 \times 2 \mathrm{~cm}$ leaf area) and high population of mite (5.37 mites $/ 2 \times 2 \mathrm{~cm}$ leaf area) was occurred during third week of October. During second week of December $\left(50^{\text {th }} \mathrm{STW}\right)$ gradually declining of mite and also minimum mite population (1.10 mites $/ 2 \times 2 \mathrm{~cm}$ leaf area) was recorded. Kandibane et al., (2009) reported that the $O$. oryzae population reached high during April May (summer) and August - September (Pre North East monsoon) in Karaikal region and gradually declining of mite was observed during November, December and January. The weather factors were closely correlated with the fluctuation in mite was recorded. Swamiappan (1986) reported that high temperature $\left(35^{\circ} \mathrm{C}\right.$ maximum and $30^{\circ} \mathrm{C}$ minimum) and dry weather for 30 days before infestation were congenial for high population of paddy spider mite. In banana the $O$. oryzae population was maximum during second fortnight of March $\left(10 / 10 \mathrm{~cm}^{2}\right.$ area) to first fortnight of June $\left(16.6 / 10 \mathrm{~cm}^{2}\right.$ area) reaching the peak during first fortnight of May $\left(26.67 / 10 \mathrm{~cm}^{2}\right)$ and the least population was recorded in first fortnight of January (0.63/10 $\mathrm{cm}^{2}$ ) (Karmakar and Dey, 2004; Karmakar and Dey, 2006). Raghavendra et al., (2017) reported the seasonal incidence of Tetranychus urticae Koch in jasmine and rose ecosystem. Initially the population of mite was least in third week of February and gradually increased in summer and maximum population was occurred during fourth week of May (34.69, 38.86 mites/leaflet). The fluctuation of mite population from $39^{\text {th }}$ standard week to $52^{\text {nd }}$ standard week and the minimum population (2.30, 3.50 mites/ leaflet) was recorded in last week of December. The correlation studies revealed that the maximum and minimum temperatures showed significant positive correlation, while morning relative humidity had a significant negative correlation, whereas evening relative humidity as well as rainfall exhibited non- significant negative correlation with $T$. urticae population in jasmine and rose ecosystem Hence the prevailing weather condition had a major impact on the population dynamics of $S$. andropogoni in sugarcane ecosystem as abiotic factors. A hot and dry weather has the growth and development of mite, whereas high rainfall and relative humidity suppressed the mite population build up, besides natural enemy activity.

\section{References}

Anonymous. 2002-2007. DRR Annual report. Mallik, B. All India National Project on Agricultural Acarology, pp 110.

Anonymous. 2018. Report of Indian Sugar Mills Association (ISMA). Online source:

(https://www.indiansugar.com/Statics.a spx)

Bairwa, B and R. N. Singh. 2013. Environmental effect on sugarcane leaf mite, Schizotetranchus andropogoni (Hirst) on sugarcane ecosystem. The Bioscan, 8(4): 1281 - 1284.

Banerjee, B. 1988. An Introduction to Agricultural Acarology: Biology and control of mite pests in the tropics. Associated Publishing Co. New Delhi, $117 \mathrm{p}$.

Deshmukh, S.Y. 2000. Ecology and control of Oligonychus indicus Hirst (Acarina: Tetranychidae) on sorghum. M.Sc. (Ag.) Thesis, submitted to N.M. College of Agriculture, GAU, Navsari.

Dubey, R.C., S. J. Maske and J. A. Ronghe. 1988. Meteorological aspects of the infestation of some pests on jowar crop. Mausam, 39: 305-308.

Ghoshal, S and S. Barman. 2012. Population dynamics and feeding potentiality of Tenuipalpus pernicis (Chaughari, Akbar and Rasool) on guava (Psidium guajava). International Journal of life 
Sciences Biotechnology and Pharma Research, 1 (2): 220 - 226.

Goulden, C.H (1972). Methods of statistical analysis. Wiley International Science Publications, John Wiley and Sons, New York, 467p.

Gubbaiah and A. K. Chakravarthy. 2002. Unusual outbreak of spider mites Oligonychus sp. on sugarcane, Saccharum officinarum in Visveshwaraiah canal tract of Mandya District, Southern Karnataka. Insect Environment, 8(2): 83 - 84.

Gupta, S. K. 1975. Schizotetranychus andropogoni (Hirst) (Acarina: Tetranychidae) a new record of paddy pest in West Bengal. Current Science, 44: 137.

Hirst, S. 1926. Description of new mites, including four new species of 'red spider'. Proceedings of the Zoological Society of London, 96 (3): 825 - 841.

Hoy, M. A.2011. Agricultural acarology: Introduction to integrated mite management. CRC Press, Boca Raton

Kandibane, M., Srimohanapriya, V and Natarajan, L. 2009. Biology and seasonal abundance of rice leaf mite, Oligonychus oryzae. Madras Agricultural Journal, 96 (7-12): 404 407.

Karmakar, K and Dey, S. 2004. Relative susceptibility of banana cultivars to spider mite Oligonychus oryzae (Hirst) (Acari: Tetranychidae), Proceedings of National Seminar on Banana IndustryPresent Scenario and Future Strategies,
11 to 13 June, 2004 BCKV, Kalyani, West Bengal.

Karmakar, K and Dey, S. 2006. Studies on seasonal incidence of phytophagous mite species on selected germplasms of banana in West Bengal. Indian Journal of Crop Sciences, 1(1-2): 138 - 39.

Mohan, S. and P. Karuppuchamy. 1987. A potential predator for sorghum mite, Oligonychus indicus (Hirst). Current Science, 56 (16): $845-846$.

Ozman - Sullivan, S. K., J. W. Amrine and D. E. Walter. 2006. A new species of eriophyid mite (Acari: Eriophyidae) on sugarcane in Australia. International Journal of Acarology, 32(4): 387 - 395.

Raghavendra, K.V., C. Chinniah, K. Ramaraju, C. Muthiah and K. Balakrishnan. 2017. Studies on seasonal incidence and integrated management of Acarine pests of major flower crops in Southern Districts of Tamil Nadu. Ph. D. (Agri.) Thesis, Tamil Nadu Agricultural University, Coimbatore.

Swamiappan, M. 1986. Mites attack in IR-56 in Malland, Tamil Nadu. International Rice Research News Letter, 11(4): 38.

Tewari, R. K., P. N. Avasthy and O. Prakash. 1982. Incidence of web mite, Schizotetranychus andropogoni Hirst on sugarcane, Indian Journal of Entomology, 44(2): 194

Verma, A. 1976. Host plant records of sugarcane mite, Schizotetranychus andropogoni Hirst, Entomologists Newsletter, 6(10): 56.

\section{How to cite this article:}

Karthick, K.S., C. Chinniah, T. Ramasubramanian, M. Kalyanasundram, K. Devrajan and Venkataraman, N.S. 2019. Seasonal Incidence and Influence of Weather Factors on the Population Dynamics of Sugarcane Web Mite, Schizotetranchyus andropogoni Hirst on Sugarcane. Int.J.Curr.Microbiol.App.Sci. 8(07): 1695-1702. doi: https://doi.org/10.20546/ijcmas.2019.807.201 